\title{
Efficacy of normal saline nasal spray and gargle on SARS- CoV-2 for prevention of COVID-19 pneumonia
}

Uday Chatterjee ( $\nabla$ udaysankarchatterjee@yahoo.com )

PARK CLINIC

\section{Ajay Chakraborty}

Department of Health and Family Welfare, GN 29, Salt Lake, Sec V, Kolkata 700091,West Bengal, India.

\section{Sishir Naskar}

Department of Health and Family Welfare, MR Bangur Hospital

\section{Bibhuti Saha}

School of Tropical Medicine

\section{Bhaswati Bandyapadhyay}

Dept of Microbiology, School of Tropical Medicine, Kolkata 700073, West Bengal, India.

\section{Subhasis Shee}

Department of Health and Family Welfare, Jangipara, Government of West Bengal, India

\section{Article}

Keywords: COVID-19, microaspiration, nasal spray, normal saline, pneumonia, SARS-CoV-2, surface virus

Posted Date: March 8th, 2021

DOI: https://doi.org/10.21203/rs.3.rs-153598/v2

License: @) (1) This work is licensed under a Creative Commons Attribution 4.0 International License. Read Full License 


\section{Abstract}

Background: Role of microaspiration of mucus mixed with SARS-CoV-2 (severe acute respiratory syndrome corona virus 2) causing pneumonia is lacking in searched literature. Recently some authors have emphasized on microaspiration. SARSCoV-2 primarily replicates in nasal mucosa and sheds in nasal mucus which travels down as microaspiration and causes pneumonia. We aimed to evaluate the efficacy of normal saline nasal spray and gargle (NSNSG) to wash off SARS-CoV-2 from nasal and pharyngeal mucosa to prevent microaspiration and pneumonia.

Methods: From RT-PCR (reverse transcriptase polymerase chain reaction) report, we selected 62 patients for study group and 63 patients for control, having higher virion load i.e. cycle threshold (Ct) value 25 or less. Patients in study group were trained with NSNSG. We reviewed HRCT (high resolution computed tomogram) of lung in 56 patients of both groups for severity score (SS) in lung and was compared with initial HRCT

Results: Thirty out of $62(48 \%)$ of study group significantly $(p=0.01)$ became RT-PCR negative following NSNSG compared to 16 out of 63 patients $(25 \%)$ of control. Thirty one out of 34 patients $(91 \%)$ of study group either improved or inhibited progression of SS in lung HRCT. In control group, 14 out of 22 patients (63\%) also showed favourable findings. Nevertheless, study group significantly improved $(p=0.028)$ in SS.

Conclusions: NSNSG is significantly efficacious to wash off SARS-CoV-2 from nasal cavity and pharynx, and to break supply chain of SARS-CoV-2 from source to prevent microaspiration in lung alveoli and pneumonia. From that phenomenon we infer that SARS-CoV-2 as a 'surface virus' and it seems that vaccine resistant SARS-CoV-2 and different strains of SARS-CoV-2 would be washed off with NSNSG.

\section{Main Text}

Morbidity and fatality depends on the severity of pneumonia in COVID-19. Published literature has contributed a lot in management of COVID-19. However, role of microaspiration of SARS-CoV-2 from upper respiratory tract causing COVID-19 pneumonia is lacking. Recently Hou et $\mathrm{al}^{1}$ have appreciated that SARS-CoV-2 migrates to lung alveoli by microaspiration from upper respiratory tract. Nasal mucosa is a fertile site for SARS-CoV-2 due highest expression of angiotensin converting enzyme2 (ACE2) receptor and transmembrane protease serine2 (TMPRSS2) in nasal epithelium. ${ }^{1,2}$ Spike protein (S) of SARS-CoV-2 sticks to ACE2 receptor, and host cell TMPRSS2 cleaves and primes S to help transfer of RNA into epithelial cell (Fig.1). RNA replicates in epithelial cell to produce virions which shed in nasal mucus to alter it as VMS (virion-mucus-suspension). Physiologically, nasal mucus is swept towards pharynx by mucociliary conveyer at a rate of $\sim 0.5 \mathrm{ml} /$ hour $^{1,3}$ and may progress to lung alveoli as microaspiration. ${ }^{1}$ Similarly, microaspiration of VMS from nasal or pharyngeal mucosa may spread inwards to infect type II alveolar epithelial cells in lung alveoli to set pneumonia.

We hypothesize that normal saline nasal spray and gargle (NSNSG) would wash away VMS, and microaspiration would be prevented. So we tested such hypothesis and found positive outcome.

\section{Methods}

Patients: In this prospective study, a total of 251 (114 study group and 137 control group) RT-PCR (reverse transcriptionpolymerase chain reaction) positive, hospital admitted, symptomatic patients with co-morbidities were enrolled from $14^{\text {th }}$ September 2020 to $4^{\text {th }}$ January 2021 in phases. All patients were capable of performing NSNSG. Informed consents were obtained from all 251 patients. Research protocol was approved by institutional ethics committees.

Nasopharyngeal and oropharyngeal swabs were collected from all patients enrolled on their respective date of admission and sent to the referral laboratory for RT-PCR test to determine Ct (cycle threshold) value. On same day patients of study 
group were trained for NSNSG physically and audio-visually. We selected 62 patients for study group and 63 patients for control group, age ranged from 18 to 80 years, from both sex, having Ct value 25 or less in RT-PCR test.

Methods: All patients got same medical treatment as per hospital protocol. Enrolled patients in study group were taught to spray $25 \mathrm{ml}$ of normal saline alternately in both nostrils from spray bottle (Fig. 2) and to gargle. They were trained to keep head slightly backwards and to opposite side to allow flow of normal saline through opposite nostril and were advised to collect effluent in a mug with soap water for safe disposal. During initial part of the study, 45 patients were on NSNSG every six hourly. In 19/45 patients, repeat RT-PCR test was done after 72 hours, and in 26/45 patients after 96 hours. Based on the results of the initial part of the study, another 17 patients were advised to increase frequency of NSNSG at three hourly intervals and RT-PCR was repeated after 120 hours. For repeat swab for RT-PCR test, NSNSG was kept on hold for six hours. RT-PCR for control group was also tested at same intervals in 21, 23 and 19 patients respectively (Table1). Serum sodium in study group and necessary investigations in both groups were done irrespective of Ct value in RT-PCR. Fifty six patients needed HRCT (high resolution computed tomogram) of lung on clinical suspicion of progression of disease and on some occasions to assure safety of NSNSG. Severity score (SS) was compared with initial HRCT of lung (Table 2).

Statistical analysis: Sampling was done using Epi-Info software version 7.3, considering $80 \%$ power, $95 \% \mathrm{Cl}$ and designing effect 1. For statistical analysis of outcome, updated excel format exported to Epi-Info software version 4.4 for both data in Table1 and Table2. P-value of significance (<0.05) for chi-square test and $95 \%$ Confidence interval for Odds ratio (OR) checked. For Table1, OR of RT-PCR negative report of study group is 2.7 times higher than control. So $95 \% \mathrm{Cl}$ for OR is 1.3 to 5.8. For Table 2, OR improvement of SS on HRCT in study group is 6.1 times higher than control. So, $95 \% \mathrm{Cl}$ for OR is 1.40 to 26.46 . As both the $95 \% \mathrm{Cl}$ don't include value 1, so the OR is significant. However, statistical analysis in SS of HRCT lung has got limitation due to its heterogeneity in comparison.

\section{Results}

We chose 62 patients in study and 63 patients in control group; having Ct value ranged 10-25 (mean 20.3) in RT-PCR. Eight out of 19 patients (42\%) and 10 out of 26 patients (38\%) of study group who did six hourly NSNSG became negative on RTPCR test done after 72 hours and 96 hours respectively. In comparison, RT-PCR became negative in 28\% (6/21) and 21\% $(5 / 23)$ of patients in control group after 72 hours and 96 hours respectively (Table-1). Subsequently 17 patients were on three hourly NSNSG and 12 of them became negative (70\%) in repeat RT-PCR done after 120 hours, compared to five out of 19 patients (26\%) of control group. Ultimately 30 out of 62 patients (48\%) of study group and 16 out of 63 patients (25\%) of control group became RT-PCR negative (Table1). Serum sodium was within normal range in study group. Efficacy of NSNSG found to be significant $(p=0.01, \mathrm{OR} 2.7,95 \% \mathrm{Cl} 1.3$ to 5.8$)$ in this study.

We evaluated HRCT chest of 34 patients from study group and 22 patients from control done on different days and compared with primary HRCT. Thirty one out of 34 patients (91\%) of study group either had improvement or no progression of severity score (SS) in lung HRCT. Similarly, 14 out of 22 patients $(63 \%)$ of control group showed favourable findings in lung SS (Table 2). Nevertheless, in study group, SS was restricted significantly ( $p=0.028,0 \mathrm{R} 6.1,95 \% \mathrm{Cl}, 1.4-26.4)$.

\section{Discussion}

In earlier part of this study, we advised six hourly NSNSG to assess tolerability as well as to assess outcome in repeat RTPCR test done after 72 hours and 96 hours. Tolerability with NSNSG was found acceptable but relative outcome in RT-PCR was not satisfactory. Six hourly NSNSG appeared insufficient to combat continuous shedding of SARS-CoV-2 from nasal epithelial cells. So we increased frequency to three hourly and found substantial clearance of virions in repeat RT-PCR done after 120 hours. It has been found, in an in vitro study ${ }^{4}$ of influenza virus, that progeny virions following replication, are continuously released from cells over a relatively longer period instead of burst-like disposal. These progeny virions following replication exploit the secretory pathway to be released out of the cells. ${ }^{5}$ This might be the basis of predilection 
of SARS-CoV-2 to infect type II alveolar epithelial cell which has got adequate secretory apparatus, like goblet cell in nasal epithelium, ${ }^{6}$ unlike type I alveolar epithelial cell. Hence continuous shedding of progeny might be expected from SARS-CoV2. So, frequent NSNSG is necessary to wash off continuous shedding of virions to protect lung from pneumonia due to microaspiration of VMS.

Hematogenous spread of SARS-CoV-2 to lung is unlikely; as demonstrated by absence of infection of micro vascular endothelial cells. ${ }^{1}$ Microaspiration from pharyngeal mucus is a well known "oral-lung aspiration axis" for many lower airways diseases. ${ }^{1,7,8}$ Macroscopically, in lung autopsy, COVID-19 infection appears patchy, segmental, and peripheral. These features are consistent with microaspirations. ${ }^{1}$

Anatomical barriers, immune mechanisms, mucociliary conveyor and cough might protect lung from microaspiration. Possibly those factors inhibited severity score from escalating in $63 \%$ patients in control group. Similarly, three patients (13\%) in control group showed no sign of microaspiration in initial HRCT as well as in HRCT done on sixth day following admission (Table 2). It appears that some patients are physiologically protected from microaspiration. Nevertheless microaspiration from nasal cavity might gain access into lungs within 10 hours particularly during sleep, as shown in earlier study with technetium $99 \mathrm{~m}$-labeled macro-aggregated albumin. ${ }^{9}$ On the other hand, microaspiration is frequently observed in older, diabetic, and obese subjects who as well are at risk for severe COVID-19. ${ }^{1}$ Appreciating the behaviour of infection, replication, shedding and microaspiration of SARS-CoV-2, it might be considered as 'surface virus' to comprehend

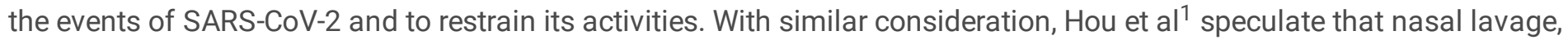
topical antiviral, or immune modulation, might be beneficial to reduce viral titer in the nose.

Soluble protease TMPRSS2 cleaves and primes S protein to facilitate fusion and helps to deliver RNA from virion to epithelial cell (Fig 1). In this study we have not examined the effect of NSNSG on soluble TMPRSS2. Nevertheless, it appears that TMPRSS2 might either be washed off or efficacy of TMPRSS2 might be decreased by NSNSG.

Co-infection with bacteria increases severity and fatality in pneumonia during influenza outbreaks. ${ }^{10}$ In many situations, bacteria and virus mutually perform to increase pathogenicity. ${ }^{11}$ Some bacteria enhance viral shedding. ${ }^{12}$ It is found that $50 \%$ of COVID-19 patients who died had bacterial co-infections in pneumonia. ${ }^{13}$ Understandably, NSNSG might wash off bacteria along with SARS-CoV-2 from nasal and pharyngeal mucosa and might decrease chance of co-infection.

Our study has got limitations. We could not study the efficacy of NSNSG on prevention of microaspiration in lung with HRCT lung in matched groups. So, we had to evaluate HRCT lung done at various intervals following admission. Secondly, patients were trained with audio-visual and physical demonstrations for NSNSG in a short period. This rapid learning appeared to be tricky in some patients. Three patients enrolled in study group failed to follow instructions correctly. They were excluded from study on 2nd day. Two patients in study group showed six and eight points increase in SS in HRCT done on sixth and seventh day (Table 2) respectively; possibly due to inadequate NSNSG following inadequate training.

We increased frequency and duration of NSNSG in phases, as we could not anticipate patients' compliance beforehand. Afterwards, three hourly NSNSG for 120 hours was found to be more effective to wash off SARS-CoV-2. We empirically used the volume of normal saline and frequency of NSNSG.

It appears that NSNSG would prevent pneumonia in COVID-19 if this procedure is applied once suspicion of contract or onset of symptoms is appreciated. Similarly, outcome would be better with proper training of patients by dedicated health workers.

\section{Conclusions}

It might be concluded that NSNSG washes off SARS-CoV-2 from nasal and pharyngeal mucosa. NSNSG breaks supply chain of microaspiration of SARS-CoV-2 from nasal and pharyngeal mucosa. So it helps injured alveoli to heal naturally.

Page 4/9 
We also infer that SARS-CoV-2 is a 'surface virus' and it is reasonable that vaccine resistant SARS-CoV-2 and different strains of SARS-CoV-2 would be washed off with NSNSG.

\section{Declarations}

Acknowledgments: The authors wish to thank the patients those agreed to participate in this study as well as doctors and nurses. We greatly appreciate Bani Chakraborty, senior sister tutor in charge, Debosmita Biswas, Ipsita Maity, Payel Paul; staff nurse of M.R. Bangur Hospital, Kolkata, India, for their active patient management for this study. We also thank all our colleagues who helped us during the current study.

Author Contributions: U.S.C conceptualized the hypothesis of this study. A.K.C., B.S., S.K.N., U.S.C. designed the study protocol. S.K.N., U.S.C. recruited patients. A.K.C., S.K.N., U.S.C. performed the study and data acquisition. A.K.C. supervised or managed research. B.B., B.S., S.K.N. supervised the RT-PCR test. A.K.C., B.B., B.S., S.K.N., U.S.C. conducted formal data analysis. Department of Health \& family welfare, Government of West Bengal, India was convinced by A.K.C. to allocate their infrastructure for this study. A.K.C., B.B., B.S., S.K.N., S.S., U.S.C. drafted the original manuscript. SS reviewed and performed statistical analysis.

Role of the funding source: There was no funding source for this study.

Declaration of interests: We declare no competing interests.

\section{References}

1. Hou, Y.J. et al. SARS-CoV-2 Reverse genetics reveals a variable infection gradient in the respiratory tract. Cell 182, 429446 (2020). https://doi.org/10.1016/j.cell.2020.05.042.

2. Matheson, N. J. \& Lehner, P.J. How does SARS-CoV-2 cause COVID-19? Science 369, 510-11 (2020). https://doi.org/10.1126/science.abc6156

3. Eichner, H., Behbehani, A.A., Hochstrasser, K. Diagnostic value of nasal secretions, current state: normal values. Laryngol Rhinol Otol 62, 561-565 (1983).

4. Frensing, T. et al. Influenza virus intracellular replication dynamics, release kinetics, and particle morphology during propagation in MDCK cells2. Appl Microbiol Biotechnol 100, 7181-92 (2016). https://doi.org/10.1007/s00253-0167542-4

5. Cortese, M. et al. Integrative imaging reveals SARS-CoV-2 induced reshaping of subcellular morphologies. Cell Host and Microbe (2020). https://doi.org/10.1016/j.chom.2020.11.003

6. Sungnak. W. et al. SARS-CoV-2 entry factors are highly expressed in nasal epithelial cells together with innate immune genes. Nature medicine 26, 681-687 (2020). https://doi.org/10.1038/s41591-020-0868-6

7. Lee, J.S. et al. Does Chronic Microaspiration Cause Idiopathic Pulmonary Fibrosis? Am J Med 123, 304-11(2010). https://dx.doi.org/10.1016\%2Fj.amjmed.2009.07.033

8. Esther, Jr CR. et al. Mucus accumulation in the lungs precedes structural changes and infection in children with cystic fibrosis. Sci Trans/ Med 11, (2019) doi:10.1126/scitranslmed.aav3488.

9. Ozcan, M. et al. Pulmonary aspiration of nasal secretions in patients with chronic sinusitis and asthma. Arch Otolaryngol Head Neck Surg 129, 1006-09 (2003).

10. Smith, A.M. \& McCullers, J.A. Secondary bacterial infections in influenza virus infection pathogenesis. Curr Top Microbiol Immuno/ 385, 327-356 (2014). https://dx.doi.org/10.3389\%2Ffmicb.2017.01041

11. Kuss, S.K. et al. Intestinal microbiota promote enteric virus replication and systemic pathogenesis. Science 334, 249252 (2011). https://doi.org/10.1126/science.1211057

Page 5/9 
12. Almand, E.A., Moore, M.D., Jaykus, L-A. Virus-Bacteria interactions: an emerging topic in human infection. Viruses 9,58 (2017). https://doi.org/10.3390/v9030058

13. Zhou, F. et al. Clinical course and risk factors for mortality of adult inpatients with COVID-19 in Wuhan, China: a retrospective cohort study. Lancet 395:1054-62 (2020). https://doi.org/10.1016/S0140-6736(20)30566-3

\section{Tables}

Table1. Total number of RT-PCR negative patients in both groups following 72, 96 and 120 hours.

\begin{tabular}{|l|l|l|}
\hline & Case & Control \\
\hline Total enrollment & 114 & 137 \\
\hline Inclusion (ct value 10-25) & 62 & 63 \\
\hline $\begin{array}{l}\text { RT-PCR Negative on 6 hourly } \\
\text { NSNSG for 72 hours }\end{array}$ & $8 / 19(42 \%)$ & $6 / 21(28 \%)$ \\
\hline $\begin{array}{l}\text { RT-PCR Negative on 6hourly } \\
\text { NSNSG for 96 hours }\end{array}$ & $10 / 26$ & $5 / 23(21 \%)$ \\
\hline $\begin{array}{l}\text { RT-PCR Negative on 3hourly } \\
\text { NSNSG for 120 hours. }\end{array}$ & $(38 \%)$ & $12 / 17$ \\
\hline $\begin{array}{l}\text { Total Number of patients became } \\
\text { RT-PCR Negative }\end{array}$ & $\begin{array}{l}5 / 19(70 \%) \\
\%)\end{array}$ \\
\hline
\end{tabular}

Table 2. SS in HRCT lung done on different days compared with the SS found on admission. 


\begin{tabular}{|c|c|c|c|c|c|c|c|c|c|}
\hline \multirow{2}{*}{\multicolumn{2}{|c|}{$\begin{array}{l}\text { Severity score (SS) } \\
\text { either was static or } \\
\text { came down or } \\
\text { increased. }\end{array}$}} & \multicolumn{6}{|c|}{ HRCT done on } & \multirow{2}{*}{$\begin{array}{l}\text { Total- } \\
\mathrm{n}=56\end{array}$} & \multirow{2}{*}{$\begin{array}{l}\text { SS } \\
\text { Improved } \\
(\%) .\end{array}$} \\
\hline & & \multirow[t]{2}{*}{$\begin{array}{l}\text { 4th } \\
\text { Day } \\
(\mathrm{n}=7)\end{array}$} & \multirow{2}{*}{$\begin{array}{l}\text { 5th } \\
\text { Day } \\
(\mathrm{n}=6) \\
\\
4\end{array}$} & \multirow{2}{*}{$\begin{array}{l}\text { 6th } \\
\text { Day } \\
(\mathrm{n}=17) \\
\\
7\end{array}$} & \multirow{2}{*}{$\begin{array}{l}\text { 7th } \\
\text { Day } \\
(\mathrm{n}=14) \\
\\
9\end{array}$} & \multirow{2}{*}{$\begin{array}{l}\text { 8th } \\
\text { Day } \\
(\mathrm{n}=6)\end{array}$} & \multirow{2}{*}{$\begin{array}{l}\text { 9th } \\
\text { Day } \\
(\mathrm{n}=6) \\
\\
2\end{array}$} & & \\
\hline Case & $\begin{array}{c}\text { Static } \\
(\mathrm{n}=13), \\
\text { came } \\
\text { down } \\
(\mathrm{n}=18) \\
\text { (range 1- } \\
6 \text { points, } \\
\text { mean } \\
2 \cdot 71)\end{array}$ & & & & & & & $\mathrm{n}=31$ & $91 \cdot 2$ \\
\hline Case & $\begin{array}{c}\text { Increased: } \\
4-8 \\
\text { points. }\end{array}$ & .. & .. & 1 & 2 & .. & .. & $\mathrm{n}=3$ & \\
\hline \multirow[t]{2}{*}{ Control } & 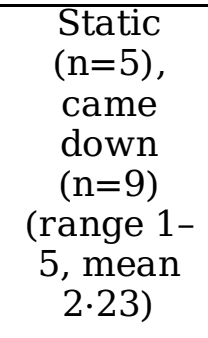 & .. & 1 & 9 & 2 & .. & 2 & $\mathrm{n}=14$ & \multirow[t]{2}{*}{$63 \cdot 6$} \\
\hline & $\begin{array}{c}\text { Increased } \\
(\mathrm{n}=8) \\
\text { (range } 1- \\
12, \text { mean } \\
4 \cdot 375)\end{array}$ & 3 & 2 & .. & 1 & 1 & 1 & $\mathrm{n}=8$ & \\
\hline $\begin{array}{l}\text { Involv } \\
50 \%, \mathrm{H} \\
\text { adding }\end{array}$ & $\begin{array}{l}\text { ment of eac } \\
\text { bint } 4=50- \\
\text { the points. }\end{array}$ & $\begin{array}{l}\text { lobe is } \epsilon \\
5 \% \text {, Poir } \\
\text { o total of }\end{array}$ & $\begin{array}{l}\text { xpressed } \\
5=>75 \\
\text { severity }\end{array}$ & $\begin{array}{l}n \text { points s } \\
\% \text { involve } \\
\text { core may }\end{array}$ & $\begin{array}{l}\text { re. Point } \\
\text { ent. Lung } \\
\text { e up to } 25\end{array}$ & $\begin{array}{l}=<5 \% \\
\text { has got } \mathrm{f} \\
\text { points }\end{array}$ & $\begin{array}{l}\text { Point } 2= \\
\text { re lobes. }\end{array}$ & $\begin{array}{l}5-25 \%, \\
S \text { is calc }\end{array}$ & $\begin{array}{l}\text { jint } 3=25- \\
\text { lated on }\end{array}$ \\
\hline
\end{tabular}

\section{Figures}




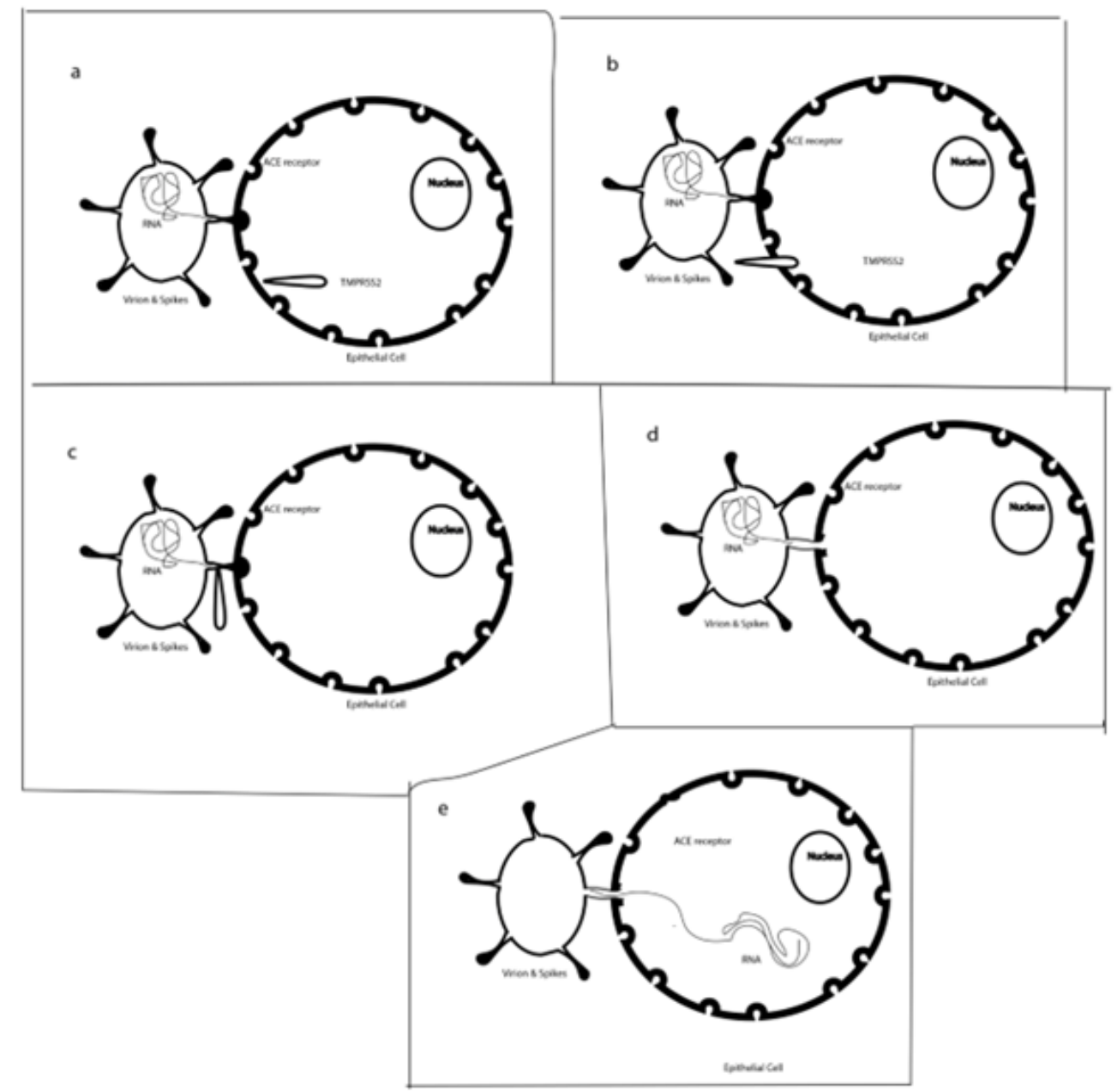

Figure 1

TMPRSS2 from host cell to facilitate transfer of RNA in epithelial cell. 


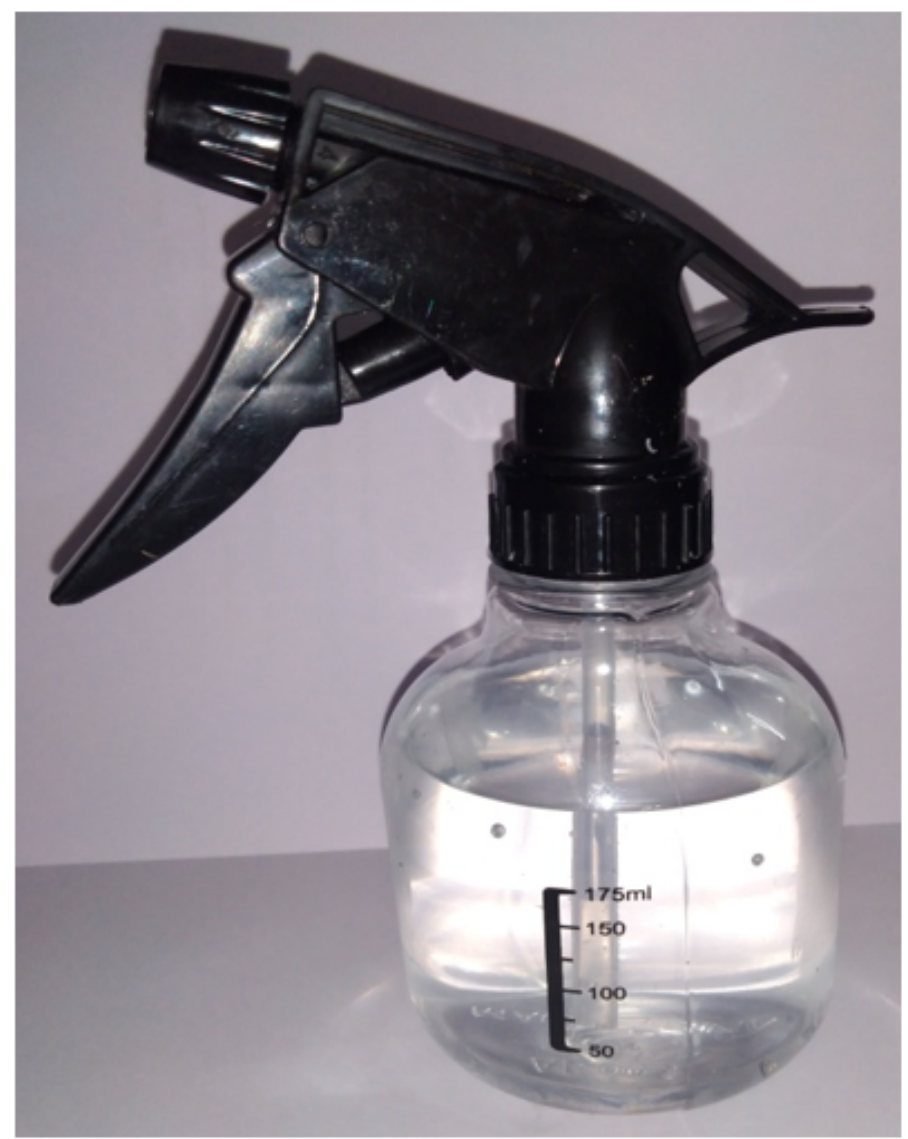

Figure 2

Spray bottle for NSNSG procedure. It delivers $0.5 \mathrm{ml}$ with each full stroke 